\title{
COMPOSITION AND FREQUENCY OF FLOWER VISITORS IN SOME VARIETIES OF MELON UNDER DIFFERENT CROP CONDITIONS ${ }^{1}$
}

\author{
EVA MONICA SARMENTO DA SILVA ${ }^{2 *}$, MARCIA DE FÁTIMA RIBEIRO ${ }^{3}$, LÚCIA HELENA PIEDADE KIILL ${ }^{3}$, \\ MÁRCIA DE SOUSA COELHO ${ }^{3}$, MARA POLINE DA SILVA $^{3}$
}

\begin{abstract}
Previous investigations showed that diverse varieties of melon may have different attractiveness for bees. Therefore, the objective of this study was to evaluate the composition, frequency and behavior of flower visitors of some melon (Cucumis melo) cultivars (Amarelo, Pele de Sapo, Cantaloupe, Gália) in different conditions (conventional and organic farming, dry and rainy seasons, with and without mulching and introduction or not of honey bee hives) in the main production poles in the Brazilian Northeast (Petrolina-PE/Juazeiro-BA, Pacajus-CE and Mossoró-RN). Observations and collections of flower visitors occurred from 5p.m. to 6p.m, in non-consecutive days. We recorded 12 species of insects, mostly bees. The most frequent was Apis mellifera (99.68\%), but other species appeared sporadically (less than 0.5\%): Xylocopa grisescens, Trigona spinipes, Plebeia sp., Melipona mandacaia, Frieseomelitta doedereleini, Halicitidae. Apis mellifera was present in all studied cultivars and sites. Xylocopa grisescens appeared in two poles, but not in Pacajus-CE, Amarelo cultivar. In addition, Trigona spinipes, although present in the three poles, was not recorded on Pele de Sapo. The Amarelo cultivar, under organic farming, without the use of mulching, and presence of honey bee hives, in the Petrolina-PE/Juazeiro-BA pole, in the dry season, was the combination of factors showing the largest number of Apis mellifera as the main visitor of melon flowers.
\end{abstract}

Keywords: Pollination. Melon. Apis mellifera. Cucumis melo.

\section{COMPOSIÇÃO E FREQUÊNCIA DE VISITANTES FLORAIS EM ALGUMAS VARIEDADES DE MELOEIRO SOB DIFERENTES SITUAÇÕES DE CULTIVOS}

RESUMO - Investigações anteriores mostraram que cultivares diversas de meloeiro podem apresentar diferente atratividade para abelhas. Portanto, o objetivo deste trabalho foi avaliar a composição, frequência e comportamento de visitantes florais de algumas cultivares do meloeiro (Cucumis melo) (Amarelo, Pele de Sapo, Cantaloupe, Gália) em variadas situações (cultivo convencional e orgânico, época seca e chuvosa, com e sem mulching e introdução ou não de colmeias de abelhas melíferas) nos principais polos de produção do Nordeste brasileiro (Petrolina-PE/Juazeiro-BA, Pacajus-CE e Mossoró-RN). As observações e coletas dos visitantes ocorreram das $5 \mathrm{~h} 00$ às $18 \mathrm{~h} 00$, em dias não consecutivos. Foram registradas 12 espécies de insetos, a maioria abelhas. Entre elas, a mais frequente foi Apis mellifera (99.68\%), mas outras espécies apareceram esporadicamente (menos de 0,5\%): Xylocopa grisescens, Trigona spinipes, Plebeia sp., Melipona mandacaia, Frieseomelitta doedereleini, Halicitidae. Apis mellifera esteve presente em todas as cultivares e locais estudados. Xylocopa grisescens apareceu em dois polos, mas não em Pacajus-CE, no tipo Amarelo. E Trigona spinipes, embora estivesse presente nos três polos, não foi registrada no Pele de Sapo. O tipo Amarelo, com cultivo orgânico, sem o uso de mulching, e presença de colmeias de abelhas melíferas, no polo Petrolina-PE/ Juazeiro-BA, na época seca, foi a combinação de fatores que apresentou maior número de Apis mellifera como principal polinizadora das flores do meloeiro.

Palavras-chave: Polinização. Melão. Apis mellifera. Cucumis melo.

\footnotetext{
*Corresponding author

${ }^{1}$ Received for publication in 06/29/2020; accepted in 03/29/2021

Paper of the Experimentation Research.

${ }^{2}$ Department of Animal Sciences, Universidade Federal do Vale do São Francisco, Petrolina, PE, Brazil; eva.silva@univasf.edu.br ORCID: 0000-0003-0187-6787.

${ }^{3}$ Research department, Empresa Brasileira de Pesquisa Agropecuária, Petrolina, PE, Brazil; marcia.ribeiro@embrapa.br - ORCID: 00000002-0839-6471, lucia.kiill@embrapa.br - ORCID: 0000-0003-0307-9634, marcia_coelhos@yahoo.com.br - ORCID: 0000-0001-59506928, marapoline@hotmail.com - ORCID: 0000-0001-6998-849X.
} 


\section{INTRODUCTION}

Research has shown that $87.5 \%$ species of plants that flower present the need for pollinator visits, being considered essential for agricultural production (OLLERTON et al., 2012; IMPERATRIZ-FONSECA et al., 2012; GIANNINI et al., $2015 \mathrm{a}, \mathrm{b})$.

The melon (Cucumis melo L.) belongs to the family Cucurbitacea, and has flowers that are very attractive to visitors, especially because they produce nectar and/or pollen as floral resources. Because such plants have heavy pollen grains, which are difficult to be carried by the wind, their pollination is entomophilous, that is, insects are the main floral visitors (KIILL et al., 2011). Among visitors to this crop, honey bees (Apis mellifera L.) stand out as effective pollinators, visiting melon flowers throughout the day (SIQUEIRA et al., 2011) in search of nectar and pollen, although at certain times they give preference to one or the other resource (RIBEIRO et al., 2017). In fact, honey bees are essential for the production of fruit in melon (SOUZA et al., 2009). In order for there to be good productivity and quality of fruit in environments with scarcity or absence of natural nests of honey bees around the cultivated area, it is necessary to introduce hives of this species (FREITAS, 1998; SOUSA et al., 2009). In the Sub-Middle São Francisco Valley, it was determined that for 1 hectare of planted area, four honey bee hives are sufficient to obtain commercial quality fruits (RIBEIRO et al., 2015).

Although bees are of great importance for improving productivity, other factors should be taken into account to assess pollination rates, such as the cultivars planted in the same cultivation area. Kiill et al. (2011) assessed three commercial types of melon (Amarelo, Pele de Sapo, Cantaloupe) in Petrolina$\mathrm{PE}$, and observed that when these types are planted in the same area, bees visit Cantaloupe flowers more than the others, and may provide a reduction in productivity for the producer.

Thus, this study aimed to identify floral visitors of different melon cultivars, under different combinations of crop conditions, in the main production poles in the country. In addition, we also intended to make inferences to their potential pollinators according to the behavior observed in floral visits.

\section{MATERIAL AND METHODS}

The experiment was conducted in experimental crops and commercial areas of the three largest melon production centers in the country: Petrolina-PE/Juazeiro-BA, Pacajus-CE and MossoróRN. In Petrolina and Juazeiro, the climate is semiarid, with average annual rainfall of $484 \mathrm{~mm}$, and rains concentrated from November to April. In Pacajus, the climate is tropical hot sub-humid, with rainfall of $791.4 \mathrm{~mm}$, and rainy period from January to April. In Mossoró, the predominant climate is semi-arid with high annual temperatures, and with rains concentrated from February to May.

The size of the planting areas is variable in each production pole. In the region of Petrolina-PE/ Juazeiro-BA, most farmers have properties of around 6 hectares, where they usually plant more than one variety or hybrid of melon. In the centers of Mossoró $-\mathrm{RN}$ and Pacajus-CE, on the other hand, the farming areas are generally much larger (more than 1,000 hectares) (KIILL et al., 2015).

The experiments were carried out in 2010 and 2011. Each planted area was $0.25 \mathrm{ha}$, with $1 \mathrm{~m}$ spacing between rows, and $0.40 \mathrm{~m}$ between plants, irrigated by dripping. The cultivars used were the hybrids Amarelo (Gladial, Araguaia, Tropical), Pele de Sapo (PS-33, Sancho) Cantaloupe (Florentino, Banzai) and Gália (McLaren, Amaregal), in a conventional and organic system. All experiments were carried out in two periods (dry and rainy), with and without the introduction of Apis mellifera honey bee hives and with and without the presence of plastic mulch on the soil (Table 1).

Data were collected from 05:00 p.m to 18:00 p.m, on non-consecutive days. Observations were made between the 20th and the 30th day after planting. This period was chosen because it is considered as the beginning of the hermaphrodite flower production, which were the only ones observed. In areas where there was more than one variety of melon cultivated, observations were made simultaneously for all cultivars. Each observation day, simultaneously, one or two observers recorded the insects that visited one or two hermaphrodite flowers, chosen according to their ease of visualization, and previously marked. The observers remained for the entire observation period of the day, observing the same flowers. These observations varied in each area studied, because sprays occasionally interrupted some of them. Thus, there was variation in the number of days (from 1 to 8 days) and hours (from 12 to 48 hours) of observation in each area and, because it was very small in some situations, it was not possible to make statistical comparisons between floral visitors in all cases. The total sampling effort dedicated to observations in the studied areas was 1,940 hours. 
Table 1. Locations, cultivars, presence of honey bee hives and mulching, types of cultivation and seasons when floral visitors were recorded in melon (Cucumis melo) crops.

\begin{tabular}{cccccc}
\hline \multirow{2}{*}{ Location } & Melon cultivars & Apis mellifera hives & Mulching & Types of cultivation & Seasons \\
\hline $\begin{array}{c}\text { Petrolina (PE)- } \\
\text { Juazeiro (BA) }\end{array}$ & Amarelo & No & No & Organic & Dry \\
& Amarelo & No & No & Conventional & Dry \\
& Amarelo & No & No & Conventional & Rainy \\
& Pele de Sapo & No & Sim & Conventional & Dry \\
& Pele de Sapo & No & Sim & Conventional & Rainy \\
& Pele de Sapo & No & No & Conventional & Dry \\
& Pele de Sapo & No & No & Conventional & Rainy \\
& Amarelo & Yes & Yes & Conventional & Rainy \\
& Amarelo & Yes & Yes & Conventional & Dry \\
& Gália & Yes & Yes & Conventional & Rainy \\
& Gália & Yes & Yes & Conventional & Dry \\
& Cantaloupe & Yes & Yes & Conventional & Rainy \\
& Cantalopue & Yes & Yes & Conventional & Dry \\
& Amarelo & No & No & Conventional & Rainy \\
& Amarelo & No & Yes & Conventional & Rainy \\
& Amarelo & Yes & Yes & Conventional & Dry \\
& Amarelo & Yes & No & Conventional & Dry \\
\hline
\end{tabular}

Some insects were collected during foraging at random, with entomological net. Then they were introduced into glass vials with paper moistened with ethyl acetate for sacrifice. Subsequently, they were mounted on an entomological pin and compared with a collection insects under a magnifying glass, to be identified taxonomically, at the level of species (as much as possible), genus and family. All other visitors observed on the flowers were only visually identified and recorded as to their frequency.

The comparisons between the different combinations of crop conditions were tested using the Kruskal-Wallis and Mann-Whitney tests.

\section{RESULTS AND DISCUSSION}

\section{Diversity and frequency of floral visitors}

In the three investigated poles, a total of 35 individuals were collected, from 12 different species belonging to four orders, on the flowers of different melon cultivars. The order Hymenoptera had the largest number: 7 individuals (58\%), when compared to the others: Diptera - $2(17 \%)$, Lepidoptera - 2 (17\%) and Coleoptera -1 (8\%).

Among the bees, the following species were found: Apis mellifera, Xylocopa grisescens Lepeletier, 1841, Trigona spinipes (Fabricius, 1793), Plebeia Schwarz, 1938 sp. and a species of the family Halictidae.

In addition to the individuals collected, the bee species were also observed and recorded: Melipona mandacaia Smith, 1863 and Frieseomelitta doederleini Friese, 1900 (Table 2).

Regarding cultivars, although with differences in each production pole, the one that attracted the largest number of visiting insect species was Amarelo (12), followed by all other cultivars (5 species each) (Table 2).

Analyzing the data by region, and all cultivars together, in the Petrolina-PE/Juazeiro-BA pole, the 
largest number of bee species $(n=12)$ was found visiting the flowers, when compared to the other regions. Mossoró-RN had the lowest number $(\mathrm{n}=9)$, while Pacajus-CE had the lowest number of all poles $(\mathrm{n}=2)$ (Table 2).

The honey bee (A. mellifera) appeared in all locations and in all cultivars. Another bee recorded in all production poles, but not in all cultivars, was $T$. spinipes. $X$. grisescens, on the other hand, was recorded in all cultivars, but it was not recorded in Pacajus-CE. The family Halictidade visited flowers of two cultivars in two production poles. And some bees (M. mandacaia, F. doederleini, Plebeia sp.) were found only in Petrolina-PE/Juazeiro-BA and in Amarelo (Table 2).

Table 2. Floral visitors of different melon cultivars (Cucumis melo: cv. Amarelo cv. Pele de Sapo cv. Cantaloupe cv. Gália $\mathrm{cv}$ ), in the production poles Petrolina-PE/Juazeiro-BA, Pacajus-CE and Mossoró-RN.

\begin{tabular}{|c|c|c|c|c|c|c|c|c|}
\hline \multirow[b]{2}{*}{ Floral visitor } & & \multicolumn{7}{|c|}{ Production Pole/Melon Cultivar } \\
\hline & & \multicolumn{3}{|c|}{ Petrolina-PE/Juazeiro-BA } & \multicolumn{2}{|l|}{ Pacajus-CE } & \multicolumn{2}{|l|}{ Mossoró-RN } \\
\hline Order & Species or Family & Amarelo & Pele de Sapo & Cantaloupe & Amarelo & Amarelo & Cantaloupe & Gália \\
\hline \multirow[t]{7}{*}{ Hymenoptera } & Apis mellifera & $\mathrm{X}$ & $\mathrm{x}$ & $\mathrm{X}$ & $\mathrm{x}$ & $\mathrm{x}$ & $\mathrm{X}$ & $\mathrm{x}$ \\
\hline & Xylocopa grisescens & $\mathrm{X}$ & $\mathrm{x}$ & $\mathrm{x}$ & - & $\mathrm{X}$ & $\mathrm{X}$ & $\mathrm{x}$ \\
\hline & Trigona spinipes & $\mathrm{X}$ & - & $\mathrm{x}$ & $\mathrm{X}$ & - & - & $\mathrm{x}$ \\
\hline & Melipona mandacaia & $\mathrm{X}$ & - & - & - & - & - & - \\
\hline & Frieseomelitta doederleini & $\mathrm{X}$ & - & - & - & - & - & - \\
\hline & Plebeia sp. & $\mathrm{X}$ & - & - & - & - & - & $\mathrm{x}$ \\
\hline & Halicitidade & $\mathrm{X}$ & - & - & - & - & $\mathrm{X}$ & - \\
\hline \multirow[t]{2}{*}{ Lepidoptera } & sp. 1 & $\mathrm{X}$ & - & $\mathrm{x}$ & - & $\mathrm{X}$ & - & - \\
\hline & sp. 2 & $\mathrm{X}$ & $\mathrm{x}$ & - & - & $\mathrm{X}$ & - & - \\
\hline \multirow[t]{2}{*}{ Diptera } & Palpada vinetorum & $\mathrm{X}$ & $\mathrm{x}$ & - & - & $\mathrm{X}$ & - & $\mathrm{x}$ \\
\hline & sp. 1 & $\mathrm{X}$ & $\mathrm{x}$ & - & - & - & - & - \\
\hline \multirow[t]{2}{*}{ Coleoptera } & Diabrotica speciosa & $\mathrm{X}$ & - & - & - & - & - & - \\
\hline & Total number of species & 12 & 5 & 4 & 2 & 5 & 3 & 5 \\
\hline
\end{tabular}

Legend: $\mathrm{x}$ : presence of the visitor; -: absence of the visitor.

These differences in the composition and frequency of visitors at different melon production poles may perhaps be explained by the variation in size of the cultivation areas, which, as already mentioned, varies in the studied locations. In addition, in some areas of Petrolina-PE, organic farming, and in Mossoró-RN, with native vegetation around the crop, a greater number of species of bees was recorded visiting the melon flowers. Organic areas, without the use of agrochemicals, and native vegetation, respectively, enabled the presence of a greater number of bee species in the crop. According to Brown and Albrecht (2001), when the crops are implanted in sites where there are areas of native vegetation, in fact, a greater diversity of bees can occur due to the existence of wild nests. In this way, crop pollination can be assisted by populations of wild bees in addition to the introduced species, including providing better results than when only honey bees, for example, are used (GARIBALDI et al., 2013).

\section{Evaluation of the main species of bees}

Table 3 lists the bees observed in the studied production poles, considering the different conditions evaluated, but only for the Amarelo cultivar, present in all poles. The statistical comparisons made, which appear in the table, were discussed below, also only for the Amarelo cultivar. 
E. M. S. SILVA et al.

Table 3. Mean number of bees recorded visiting Amarelo cultivar melon flowers in the studied production poles (Petrolina$\mathrm{PE} / \mathrm{Juazeiro}$, Pacajus-CE and Mossoró-RN), considering the presence or absence of mulching, the type of cultivation (conventional or organic farming) and season (rainy or dry), in areas without and with the addition of honey bee hives.

\begin{tabular}{|c|c|c|c|c|c|c|c|}
\hline Production pole & Hive presence & Mulching presence & Type of cultivation & Season & Apis mellifera & Xylocopa grisescens & Trigona spinipes \\
\hline \multirow{4}{*}{$\begin{array}{c}\text { Petrolina-PE/ } \\
\text { Juazeiro-BA }\end{array}$} & No & No & Conventional & Rainy & $\begin{array}{c}124.91 \pm 127.01^{\mathrm{A}, \mathrm{a}} \\
(\mathrm{n}=22)\end{array}$ & $\begin{array}{c}0.59 \pm 1.01^{\mathrm{A}, \mathrm{a}} \\
(\mathrm{n}=22)\end{array}$ & $\begin{array}{c}0 \\
(\mathrm{n}=22)\end{array}$ \\
\hline & No & No & Conventional & Dry & $\begin{array}{c}355.17 \pm 130.83^{\mathrm{B}, \mathrm{a}} \\
(\mathrm{n}=29)\end{array}$ & $\begin{array}{c}0.79 \pm 1.11^{\mathrm{A}, \mathrm{a}} \\
(\mathrm{n}=29)\end{array}$ & $\begin{array}{l}0.07 \pm 0.26 \\
(\mathrm{n}=29)\end{array}$ \\
\hline & No & No & Orgânico & Rainy & $\begin{array}{c}352.00 \pm 66.65^{\mathrm{A}, \mathrm{a}} \\
(\mathrm{n}=5)\end{array}$ & $\begin{array}{c}0.40 \pm 0.55^{\mathrm{A}, \mathrm{a}} \\
(\mathrm{n}=5)\end{array}$ & $\begin{array}{c}0 \\
(\mathrm{n}=5)\end{array}$ \\
\hline & No & No & Orgânico & Dry & $\begin{array}{c}371.40 \pm 205.34^{\mathrm{A}, \mathrm{a}} \\
(\mathrm{n}=15)\end{array}$ & $\begin{array}{c}1.13 \pm 1.36^{\mathrm{A}, \mathrm{a}} \\
(\mathrm{n}=15)\end{array}$ & $\begin{array}{c}0.33 \pm 0.99 \\
(\mathrm{n}=15)\end{array}$ \\
\hline \multirow{4}{*}{ Pacajus-CE } & No & Yes & Conventional & Rainy & $\begin{array}{c}53.00 \pm 26.10^{\mathrm{A}, \mathrm{a}} \\
(\mathrm{n}=5)\end{array}$ & $\begin{array}{c}0 \\
(\mathrm{n}=5)\end{array}$ & $\begin{array}{c}12.00 \pm 11.62^{\mathrm{A}, \mathrm{a}} \\
(\mathrm{n}=5)\end{array}$ \\
\hline & No & No & Conventional & Rainy & $\begin{array}{c}85.80 \pm 31.83^{\mathrm{A}, \mathrm{a}} \\
(\mathrm{n}=5)\end{array}$ & $\begin{array}{c}0 \\
(\mathrm{n}=5)\end{array}$ & $\begin{array}{c}6.20 \pm 9.12^{\mathrm{A}, \mathrm{a}} \\
(\mathrm{n}=5)\end{array}$ \\
\hline & Yes & Yes & Conventional & Dry & $\begin{array}{c}269.80 \pm 66.84^{\mathrm{A}, \mathrm{b}} \\
(\mathrm{n}=5)\end{array}$ & $\begin{array}{c}0 \\
(\mathrm{n}=5)\end{array}$ & $\begin{array}{c}68.60 \pm 11.33^{\text {A.b }} \\
(\mathrm{n}=5)\end{array}$ \\
\hline & Yes & No & Conventional & Dry & $\begin{array}{c}295.20 \pm 51.36^{\mathrm{A}, \mathrm{b}} \\
(\mathrm{n}=5)\end{array}$ & $\begin{array}{c}0 \\
(n=5)\end{array}$ & $\begin{array}{c}55.80 \pm 7.92^{\mathrm{A}, \mathrm{b}} \\
(\mathrm{n}=5)\end{array}$ \\
\hline \multirow{2}{*}{ Mossoró-RN } & Yes & Yes & Conventional & Rainy & $\begin{array}{l}1453 \\
(\mathrm{n}=1)\end{array}$ & $\begin{array}{c}4 \\
(n=1)\end{array}$ & $\begin{array}{c}0 \\
(\mathrm{n}=1)\end{array}$ \\
\hline & Yes & Yes & Conventional & Dry & $\begin{array}{c}672 \\
(\mathrm{n}=1)\end{array}$ & $\begin{array}{c}3 \\
(\mathrm{n}=1)\end{array}$ & $\begin{array}{c}0 \\
(\mathrm{n}=1)\end{array}$ \\
\hline
\end{tabular}

Legend: $\mathrm{n}=$ number of observation days.

Different letters indicate significant differences at the 5\% level (Mann-Whitney); absence of letters indicates that the results, being zero or close to these values, could not be compared to each other. Comparisons were made only on the same species of bees under different conditions.

\section{Apis mellifera}

Honey bees were the most commonly recorded visiting the flowers of all melon cultivars and in all production poles, with an absolute number of 18,466 individuals $(99.68 \%)$. All other bees were much less frequent $(<0.5 \%)$ in their visits to the observed flowers.

The fact that Apis mellifera is the most abundant in all areas studied (Table 2) could be related to the presence of natural nests surrounding the crop, with the exception of Mossoró-RN, where this abundance was attributed mainly to the placement of hives in the crop, which is a common practice in the municipality, which obviously increases its density in the cultivation area (RIBEIRO; SILVA; LIMA, 2012). Moreover, according to Winfree et al. (2009) and Garibaldi et al. (2011), this bee may be less affected by the effects of human activities on the landscape composition when compared to solitary bees, which would thus justify its frequent presence in almost all environments. $T$. spinipes also occurs in open and anthropized areas (JAFFÉ et al., 2015).

Another point to be considered is the radius of action of honey bees, which is much larger than other species. However, Xylocopa sp. also has a wide radius of action and was not frequent in melon flowers. Nests of $A$. mellifera are very populous, with up to 80,000 individuals (FREITAS, 1998), which could also explain its high frequency in flowers. On the other hand, Trigona spinipes also has nests as populous as Apis mellifera (JAFFÉ et al., 2014). Thus, the high frequency of honey bees cannot be explained by these factors alone. Perhaps there is a preference of bees for floral resources offered by melon flowers. Previous studies (KIILL et al., 2011; RIBEIRO et al., 2017) have indeed shown that they were the most abundant in visits to melon flowers throughout the observation period.

As already mentioned, all statistical comparisons were made only with the Amarelo cultivar. Most comparisons made between the different conditions evaluated in this study did not indicate significant differences $(\mathrm{p}>0.05)$ in Petrolina -PE/Juazeiro-BA (Table 3). The only exception was between the dry and rainy season, for the Amarelo melon, conventional farming cultivation, without mulching and without the introduction of a hive $(\mathrm{p}=0.001)$. In the dry season, there was a significantly greater presence of honey bees (on average 355), on melon flowers than in the rainy season (approximately 125). This should have occurred due to the low availability of other food resources around the area in the dry season, which forced the bees to visit the melon flowers more 
intensively. In the rainy season, on the other hand, there was greater availability of floral resources, in addition to melon flowers.

Comparing conventional and organic farming systems in Petrolina-PE/Juazeiro-BA, in the two rainy seasons, without mulching and without hives, there was also a significant difference $(\mathrm{p}=0.011)$. The organic cultivation presented more than twice as many bees (352 individuals) than the conventional system (125). This probably occurred because pesticides that can cause a decrease in floral visitors were used (SIQUEIRA et al., 2012; PIRES et al., 2016). On the other hand, when compared to the dry season, there was no significant difference between the number of bees present in conventional and organic crops $(p=0.759)$. In the dry season, the use of agrochemicals is less frequent, since the crop is little affected by pests and diseases, which occurs in high incidence in the rainy season, when the use of agrochemicals is intensified.

In Pacajus-CE, comparisons between all treatments (Table 3) also did not show significant differences $(p>0.05)$. The presence or absence of mulching did not result in differences in the number of individuals present on the flowers contradicts Siqueira et al. (2017). In this last study, the presence of mulching significantly reduced the frequency of honey bees on flowers of the Amarelo cultivar, comparing crops located in Petrolina-PE/-BA, Juazeiro and Pacajus-CE. This was probably due to the increase in temperature of the soil (and the flowers, which are creeping) caused by the black plastic cover. Nevertheless, the data were evaluated by time and adding the results obtained in the dry and rainy seasons, differently from the present study. Even so, the mean values found in the present study were much higher without the presence of mulching than with it, even without statistical significance (Table 3), suggesting the same trend of the results obtained by Siqueira et al. (2017). In fact, the increase in soil temperature caused by the use of mulching can vary depending on several factors, such as the planting stage, color of the material and the ability to reflect and transmit solar energy (BHARDWAJ; KENDRA, 2013). Thus, according to this publication, at flowering the temperature increase can be from 0.8 to $1.9^{\circ} \mathrm{C}$ and black mulching (which is more used for planting melons in Petrolina-PE/Juazeiro-BA), would be responsible for an increase of $0.8^{\circ} \mathrm{C}$ in the soil.

Considering also Pacajus-CE, Amarelo cultivar, under conventional farming, with and without hive, with mulching, in the dry and rainy seasons, there was a significant difference $(\mathrm{p}=0.012)$ : there were approximately 270 bees present in the flowers against only 53, respectively (Table 3). Likewise, even without mulching, again with and without bee hives, the difference between the dry and rainy seasons was also significant $(\mathrm{p}=0.012)$, with 295 and 85 bees, respectively. Again, the dry season presented the highest number, confirming the results found in Petrolina-PE/Juazeiro -BA. However, in these comparisons, as there were two variables (hive presence and season), it is possible that both factors have acted synergistically. It is not possible to state that only the presence of hives was determinant for the largest number of bees found in melon flowers.

It was not possible to statistically compare the data from Mossoró-RN for the Amarelo melon cultivar, because only one sample was collected in this production pole. However, if we compare similar conditions (conventional crop, with beehive, with mulching, in the dry season), between Pacajus$\mathrm{CE}$ and Mossoró-RN, we find that in this last location, the number of $A$. mellifera was more than double the first (672 and 269, respectively, Table 3). This was probably because in Mossoró-RN there was also the visitation of honey bees from the native forest areas surrounding the crops, which is a common characteristic in that production pole (RIBEIRO; SILVA; LIMA, 2012). Thus, the number of bees on the melon flowers may have been increased by them, in addition to those originating from the introduced hives.

Contrary to what was observed in the other two production centers, in Mossoró there was a greater number of bees visiting the flowers in the rainy season than in the dry season (1453 and 672, respectively). There is no way to state the reason for this, since no further studies were conducted. As an example, if there was knowledge about the composition of plant species providing floral resources in the surrounding areas and/or the presence of wild nests close to the crop, it might be possible to justify the presence of a greater number of honey bees in the rainy season. Another possibility would be the general condition of the hives introduced in the crop, which could be healthy in the rainy season, with a large number of workers and, due to lack of management, had weakened in the dry period, thus presenting few individuals. It is also worth remembering that in Mossoró, the sampling was very small, which does not allow to draw more assertive conclusions.

\section{Xylocopa gricescens}

Considering only the Amarelo cultivar, this bee was observed at the poles of Petrolina-PE/ Juazeiro-BA and Mossoró-RN. Again, the comparisons did not indicate significant differences ( $>>0.05$ ) when, in each cultivation (organic and conventional farming), the dry and rainy seasons 
were compared. However, a greater number of individuals was found visiting the organic melon flowers in the dry season compared to conventional cultivation during the rainy season. With respect to the dry seasons, in the two farming systems (organic and conventional), again there was no significant difference $(p=0.427)$. The same occurred with the comparison in the rainy season $(\mathrm{p}=0.803$; Table 3$)$.

The low number of these bees may have been caused by the low supply of nesting sites, that is, dead and/or hollow trees (PEREIRA; GARÓFALO, 2010; MARTINS et al., 2014) in the areas surrounding the crop, as well as greater number of floral resources available in their flight radius and, consequently, little interest in melon flowers.

\section{Trigona spinipes}

In the Amarelo cultivar, this species occurred in Petrolina-PE/Juazeiro-BA and Pacajus-CE. Similar to $A$. mellifera and $X$. grisescens, in this study numerically more individuals of $T$. spinipes were found in the dry than in the rainy season. However, when comparing the two dry seasons and the two rainy seasons, with and without mulching, no significant differences were detected $(p>0.05$; Table 3).

On the other hand, still in Pacajus-CE, with conventional farming, with mulching, comparing dry and rainy season, the number of $T$. spinipes was significantly higher (68.60) in the first than in the second (12.00) $(\mathrm{p}=0.008$; Table 3$)$. The same occurred when the areas did not have mulching: the number of $T$. spinipes was significantly higher (55.80) in the dry season than in the rainy season (6.20) $(\mathrm{p}=0.008$; Table 3).

Nests of these bees are populous (RIBEIRO, 2010) and, in the dry season mainly, they need to seek different resources to feed their brood. Possibly, areas where this species was more abundant had nests in the vicinity of the crop.

\section{Foraging behavior and resources collected from flowers}

As for the behavior of bees during visits to flowers, most visitors came into contact with the reproductive structures during nectar and/or pollen foraging. The exception was for Plebeia sp., which was considered a nectar plunderer, since during the collection of this resource, it did not come into contact with the flower stigma. Only A. mellifera and $T$. spinipes were considered effective pollinators due to the frequency and behavior during visits to flowers. Only these bees collected both floral resources (nectar and pollen).

The other insects (other Hymenoptera, Diptera and Coleoptera) were considered as potential pollinators, since, although they could come into contact with the reproductive structures, their visits were rare. Lepidoptera was considered a plunderer.

\section{CONCLUSIONS}

Bees were the main floral visitors of melon flowers with the largest number of specimens and species. Apis mellifera was the main pollinating agent of melon because it is very common in all environments, is present in adequate number and has a foraging behavior that can effectively transfer pollen from the anthers to the stigmas. The stingless bee Trigona spinipes and Xylocopa grisescens could also contribute, to a lesser extent, to the pollination of melon.

In fact, in several crops, pollination can be aided by populations of wild bees in addition to the introduced species, even providing better results than when only honey bees, for example, are considered (GARIBALDI et al., 2013).

After this study, it was reaffirmed that other bees can also contribute to the pollination of melon, in addition to managed bees (honey bees) (KLEIN et al., 2020).

In the present study, the Amarelo cultivar attracted the largest number of bee species, followed by Cantaloupe, and Pele de sapo and Gália. However, the same number of areas was not observed for each cultivar, and not under simultaneous planting conditions. Only in this way, it would be possible to affirm if, effectively, the Amarelo cultivar is the most attractive for honey bees. Another study (KIILL et al., 2011) showed that under simultaneous cultivation of three melon cultivars (Amarelo, Cantaloupe and Pele de Sapo), several factors could influence the visitation of flowers by honey bees. Among these factors would be the flower type (hermaphrodite or male flower) and the flower morphology and size, floral resource offered (nectar or pollen) and visiting hours throughout the day. In this study, both Cantaloupe and Amarelo received the most visits from honey bees.

According to the results found herein, it is possible to state that, in general, the Amarelo cultivar, under organic farming, without mulching, and the presence of honey bee hives, in Petrolina-PE/ Juazeiro-BA pole, in the dry season, was the combination of factors that resulted in the highest number of Apis mellifera as the main visitor to melon flowers.

\section{ACKNOWLEDGEMENTS}

We are grateful to the farmers of all the studied locations, who allowed data collection to be carried out; to the National Council for Scientific and 
Technological Development $(\mathrm{CNPq})$ and Food and Agriculture Organization (FAO), for financing and to Embrapa, for facilities and infrastructure.

\section{REFERENCES}

BHARDWAJ, R. L.; KENDRA, K. V. Effect of mulching on crop production under rainfed condition - a review. Agricultural Reviews, 34: 188-197, 2013.

BROWN, J. C.; ALBRECHT, C. The Effect of Tropical Deforestation on Stingless Bees of the Genus Melipona (Insecta: Hymenoptera: Apidae: Meliponini) in Central Rondônia, Brazil. Journal of Biogeography, 28: 23-634, 2001.

FREITAS, B. M. A importância relativa de Apis mellifera e outras espécies de abelhas na polinização de culturas agrícolas. In: Encontro sobre Abelhas, n ${ }^{0}$ 3. 1998, Ribeirão Preto. Anais... Ribeirão Preto: USP, 1998, p. 10-20.

GARIBALDI, L. A. et al. Stability of pollination services decreases with isolation from natural areas despite honey bee visits. Ecology Letters, 14: 10621072, 2011.

GARIBALDI, L. A. et al. Wild Pollinators Enhance Fruit Set of Crops Regardless of Honey Bee Abundance. Science, 339: 1608-1611, 2013.

GIANNINI T. C. et al. Crop pollinators in Brazil: a review of reported interactions. Apidologie, 46: 209223, 2015a.

GIANNINI, T. C. et al. The dependence of crops for pollinators and the economic value of pollination in Brazil. Journal of Economic Entomology, v. 108, p. $849-857,2015$ b.

IMPERATRIZ-FONSECA, V. L. et al. Polinizadores no Brasil. Contribuição para a biodiversidade, uso sustentado, conservação e serviços ambientais. São Paulo, SP: Edusp, p. 2012. p. 488 .

JAFFÉ, R. et al. Monogamy in large bee societies: a stingless paradox. Naturwissenschafte, 101: 261264, 2014.

JAFFÉ, R. et al. Landscape genetics of a tropical rescue pollinator. Conservation Genetics, 17: 267278, 2015.

KLEIN, A. M. et al. A polinização agrícola por insetos no Brasil: Um Guia para Fazendeiros, Agricultores, Extensionistas, Políticos e Conservacionistas. 1. ed. Fortaleza, CE: UNIFR,
2020. 149 p.

KIILL, L. H. P. et al. Avaliação do padrão de visitação de Apis mellifera em três cultivares de meloeiro em Petrolina-PE, Brasil. Revista Brasileira de Fruticultura, 33: 455-460, 2011.

KIILL, L. H. P. et al. Plano de manejo de polinizadores do meloeiro. 1. ed. Petrolina, PE: Embrapa Semiárido, 2015. 267 p. (Documentos, 18).

MARTINS, C. F. et al. Density and Distribution of Xylocopa Nests (Hymenoptera: Apidae) in Caatinga Areas in the Surroundings of Passion Fruit Crops. Neotropical Entomology, 43: 314-321, 2014.

OLLERTON, J. et al. Overplaying the role of honey bees as pollinators: A comment on Aebi and Neumann (2011). Trends in Ecology and Evolution, 27: 141-142, 2012.

PIRES, C. S. S. et al. Enfraquecimento e perda de colônias de abelhas no Brasil: há casos de CCD? Pesquisa Agropecuária Brasileira, 51: 422-442, 2016.

PEREIRA, M.; GARÓFALO, C. A. Biologia da nidificação de Xylocopa frontalis e Xylocopa grisescens (Hymenoptera, Apidae, Xylocopini) em ninhos-armadilha. Oecologia Australis, 14: 193209, 2010.

RIBEIRO, M. F. Abelha irapuá: comportamento polinizador e destrutivo em plantas nativas e cultivadas. In: II SEMANA DOS POLINIZADORES, 2009, Petrolina. Anais... Petrolina: Embrapa Semiárido. 2010. p. 83.

RIBEIRO, M. F.; SILVA, E. M. S.; LIMA, C. B. S. Comparação da utilização de colméias de abelhas melíferas (Apis mellifera) para a polinização em cultivos de melão (Cucumis melo) nas regiões de Mossoró (RN) e Salitre (BA). In: CONGRESSO BRASILEIRO DE APICULTURA, 19., E CONGRESSO BRASILEIRO DE MELIPONICUlTURA, 5., 2012, Gramado. Anais... Gramado: APACAME, 2012. p. 66-66.

RIBEIRO, M. F. et al. Honey bees (Apis mellifera) visiting flowers of yellow melon (Cucumis melo) using different number of hives. Ciência Rural, 45: 1768-1773, 2015.

RIBEIRO, M. F. et al. Resource Collection by Honeybees (Apis mellifera) on Yellow Melon (Cucumis melo) Flowers. Journal of Agricultural Science; 9: 15-20, 2017.

SIQUEIRA, K. M. M. et al. Comparação do padrão 
de floração e de visitação do meloeiro do tipo amarelo em Juazeiro-BA. Revista Brasileira de Fruticultura, 33, 455-460, 2011.

SIQUEIRA, K. M. M. et al. Effect of agrochemicals on the pattern of visitation of honey bees (Apis mellifera) in melon (Cucumis melo) flowers in Brazilian Northeast. Julius-Kühn-Archives, 437: 180-183, 2012.

SIQUEIRA, K. M. M. et al. A importância dos polinizadores na cultura de Cucumis melo em cultivo com e sem cobertura plástica. Horticultura Argentina, 36: 59-66, 2017.

SOUSA, R. M. et al. Requerimentos de polinização do meloeiro (Cucumis melo) no município de Acaraú -CE-Brasil. Revista Caatinga, 22: 238-242, 2009.

WINFREE, R. et al. A meta-analysis of bee responses to anthropogenic disturbance. Ecology, 90: 2068-2076. 2009. 